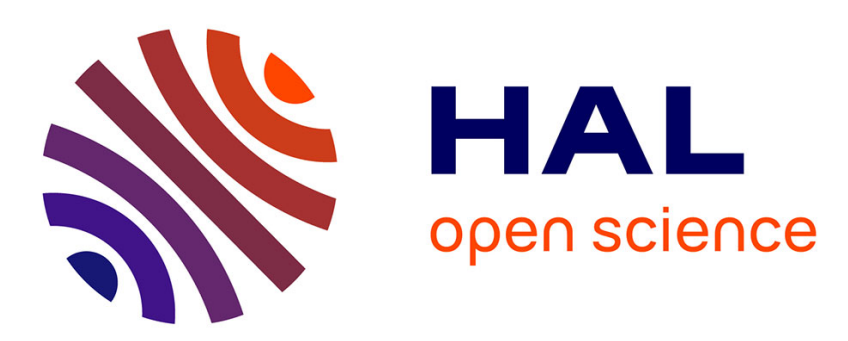

\title{
How French general practitioners respond to declining medical density: a study on prescription practices, with an insight into opioids use
}

\author{
Julien Silhol, Bruno Ventelou, Anna Zaytseva
}

\section{- To cite this version:}

Julien Silhol, Bruno Ventelou, Anna Zaytseva. How French general practitioners respond to declining medical density: a study on prescription practices, with an insight into opioids use. European Journal of Health Economics, 2020, 21 (9), pp.1391-1398. 10.1007/s10198-020-01222-8 . hal-02944339

\section{HAL Id: hal-02944339 \\ https://hal-amu.archives-ouvertes.fr/hal-02944339}

Submitted on 15 Feb 2021

HAL is a multi-disciplinary open access archive for the deposit and dissemination of scientific research documents, whether they are published or not. The documents may come from teaching and research institutions in France or abroad, or from public or private research centers.
L'archive ouverte pluridisciplinaire HAL, est destinée au dépôt et à la diffusion de documents scientifiques de niveau recherche, publiés ou non, émanant des établissements d'enseignement et de recherche français ou étrangers, des laboratoires publics ou privés. 
Title: How French general practitioners respond to declining medical density: a study on prescription practices, with an insight into opioids use

\section{Authors:}

Julien SILHOL - julien.silhol@insee.fr

Bruno VENTELOU (corresponding author) - bruno.VENTELOU@univ-amu.fr, ORCID 0000-0003-0774-1525

Anna ZAYTSEVA - anna.zaytseva@univ-amu.fr

\section{Affiliations:}

J. SILHOL:

1. Institut National de la Statistique et des Etudes Economiques (Insee), Montrouge, France.

2. Aix-Marseille University, CNRS, EHESS, Centrale Marseille, AMSE, Marseille, France.

B. VENTELOU \& A. ZAYTSEVA: Aix-Marseille University, CNRS, EHESS, Centrale Marseille, AMSE, Marseille, France.

Acknowledgements: We thank Gwenaëlle Maradan and her survey team from Observatoire Régional de la Santé, and our panel of GPs. We also thank bureau de professions de santé of DREES, French ministry of health for their continuous and valuable support throughout the data collection process.

Funding: This work was supported by French National Research Agency grant ANR17-EURE-0020 and French Institute for Public Health Research grant $\mathrm{n}^{\circ}$ IReSP-LIAAP18-HSR-008. A.Z. received a PhD grant from the (non-profit) Sud Provence-AlpesCôte d'Azur regional council.

Conflict of Interest: The authors declare that they have no conflict of interest. 
How French general practitioners respond to declining medical density: a study on prescription practices, with an insight into opioids use (4401 words) 


\begin{abstract}
(168 words)
Disparities in physicians' geographical distribution lead to highly unequal access to healthcare, which may impact quality of care in both high and low-income countries. This paper uses a 2013-2014 nationally representative survey of French general practitioners (GPs) matched with corresponding administrative data to analyze the effects of practicing in an area with weaker medical density. To avoid the endogeneity issue on physicians' choice of the location, we enriched our variable of interest (practicing in a relatively underserved area) with considering changes in medical density between 2007 and 2013, thus isolating GPs who only recently experienced a density decline (identifying assumption). We find that GPs practicing in underserved areas do shorter consultations and tend to substitute time-consuming procedures with alternatives requiring fewer human resources, especially for pain management. Results are robust to considering only GPs newly exposed to low medical density. Findings suggest a significant impact of supply-side shortages on the mix of healthcare services used to treat patients, and point to a plausible increased use of painkillers, opioids in particular.
\end{abstract}

Keywords: Health workforce, Medically Underserved Area, General Practitioners, Prescriptions, Opioids, France

JEL classification: I14, I18, C31. 


\section{Introduction}

France's primary care medical density is one of the highest among the countries of the Organization for Economic Co-operation and Development [1]. In 2013, there was almost one GP per 1,000 inhabitants in France, while the density was around 0.7 in Germany, 0.8 in the Netherlands, Italy and the United Kingdom, 1.1 in Belgium, 2.0 in Portugal and 0.3 in the United States $^{1}$ [1]. However, the geographical distribution of General Practitioners (GPs) is very uneven [2-6] and, actually, some parts of the French territory could be qualified as a "medical desert" [7]. Private physicians in France, including GPs, choose freely where they wish to practice and are paid a regulated fee. As a consequence, neither the government nor the market have managed to prevent the emergence of relatively underserved areas (that could be defined as below a threshold density). Increasing numbers of these areas are expected due to recent and very strong demographic trends ${ }^{2}$. The number of GPs started to decrease in 2010 and, according to French ministry of health forecasts, medical density should continue to decline up to 2027. A growing and aging French population, including an increasing number of patients suffering from chronic illnesses, will encounter decreasing numbers of GPs. In addition, new generation GPs undertake, on average, fewer consultations than those who are close to retirement $[9,10]$.

Accentuating the problem is the fact that French self-employed GPs not only provide more than $90 \%$ of primary care [11] but also carry out gatekeeping functions. By ensuring a match between demand and supply from various healthcare professionals, GPs are essential to the proper functioning of the whole health system [12]; but despite that, in France, they are selfemployed, in private practices, without hierarchical constraints from the public health authority nor health insurances. It is therefore vital to better understand how GPs located in relatively underserved areas are adapting their practices. Despite numerous studies comparing

\footnotetext{
1 This comparison should be interpreted with caution, since the functioning of the health systems is not similar across countries.

${ }^{2}$ From 2010 to 2030 , population is expected to increase by $9 \%$, and the population aged over 60 by $30 \%$, according to the French national statistical institute (INSEE). Especially due to this ageing population, the proportion of the population with chronic diseases increases too. For instance, from 14,4\% in 2011 to $16,0 \%$ in 2016 [8].
} 
healthcare access in rural and urban settings [13-15], both in low- and high-income countries, there have been very few comprehensive quantitative studies linking healthcare professional shortages with the quantity and quality of care received by local populations [16-18].

\section{Methods}

We used data from the third round (2013-2017) of a national panel survey of French private practice GPs, designed to collect information about GPs' medical practices, working conditions and opinions on public health policies. The method used to set up the panel has been detailed elsewhere [19]. Briefly, GPs were randomly selected from a French exhaustive database of health professionals as of end of 2010. Sampling was stratified for gender, age, workload and medical density. The survey is representative of GPs practicing in mainland France, except those planning to retire or to move before the end of data collection and those exclusively practicing alternative medicine. Of the 2,988 eligible GPs, 1,712 (57\%) completed the inclusion questionnaire and undertook to answer five future cross-sectional surveys (one every nine months). The National Authority for Statistical Information (Commission Nationale de I'Information Statistique) approved the panel.

Professional interviewers used a computer-assisted telephone interview system to collect data with questionnaires that were pilot-tested for clarity and face validity among 50 GPs. GPs received compensation equivalent to one consultation fee for their participation in each survey.

We used data from the inclusion (2013-2014) questionnaire on GPs' working conditions and practice organization. For consenting GPs (1,553 GPs: $91 \%$ of the sample), the data was enriched with 2013 Social Security electronic reimbursement records providing a summary of their activity: the number of office consultations and house calls, aggregate patient characteristics (e.g. proportion of patients aged $>60$ years) and prescription data (by Anatomical Therapeutic Chemical Classification (ATC) class). 
For the descriptive analyses, data were weighted to match the mainland France GP population in terms of medical density in 2010 (Q1, Q2-Q3, Q4), gender, age $(<50,50-58,>58$ at inclusion) and workload (in 2010: Q1, Q2-Q3, Q4).

We construct our variable of interest using a GP density indicator at health-area level [20]. A health area is delimited by patient access-to-care flows; there are about 2,700 health areas in mainland France. In 2013 , the average density was 9.2 GPs per 10,000 inhabitants. The $25 \%$ of the most underserved health areas had less than 7.1 GPs per 10,000 inhabitants, while the $25 \%$ of the most well served health areas had at least 10.8 GPs per 10,000 inhabitants. We define areas with less than 8 GPs per 10,000 inhabitants as relatively underserved areas. This threshold corresponds to the average GP density expected in France in a few years [9]. According to this threshold, $27 \%$ of GPs in our sample can be considered to practice in relatively underserved areas in $2013(20 \%$ in 2007$)$.

As mentioned above, French GPs perform two main functions: gatekeeping and prescribing, including drugs, healthcare professionals, lab tests and sickness benefits. To cover all these dimensions, we define a set of dependent variables regarding GPs' working conditions: working hours per week, workload (annual number of consultations and house calls), patient list, pace of consultations ${ }^{3}$ and prescribing practices (per patient): 1) total drug prescription volume; 2) specific drug prescriptions: painkillers (non-steroid anti-inflammatory drugs and opioids), antibiotics and antidepressants; 3) lab tests and 4) healthcare professionals (nurses, physical therapists) .

We use multivariate linear regressions ${ }^{4}$ to estimate the following model (Model 1 ):

$$
Y_{i}=\alpha+\beta * \text { relatively underserved }+\gamma X_{i}+\epsilon_{i}
$$

\footnotetext{
3 Total number of consultations divided by declared working hours; denominator derived from 2013 question on working hours: "During last/a typical week, how much time did you spend on your private GP activities?" adjusted for vacations [21].

${ }^{4}$ We computed the variance inflation factor (VIF) to test for multicollinearity and interpreted VIF values less than five as presenting no multicollinearity issues.
} 
where

- $\mathrm{Y}$ is one of the dependent variables described above, observed for GP $i$

- Relatively underserved is a dummy variable indicating practicing in a relatively underserved area,

- $X$ is a set of control variables that includes GP $i$ personal and professional characteristics (gender, age, possible use of unregulated fees ${ }^{5}$, group practice), practice community characteristics (municipality type, municipality median revenue, located in Paris) and patient list characteristics (proportion of patients aged $<16, \geq 60$ or deprived patients) as well as paramedics density (where applicable - Models 1a, 2a). We then perform a sensitivity analysis using alternative threshold values: 7 and 9 per 10,000 inhabitants ${ }^{6}$. Furthermore, we control for possible endogeneity of location choice using the difference between 2007 and 2013 medical density indicators (Model 2). We distinguish three categories: never underserved, newly underserved (in 2013, but not in 2007), still underserved. We therefore estimate:

$$
Y_{i}=\alpha+\beta_{1} * \text { newly underserved }{ }_{i}+\beta_{2} * \text { always underserved }_{i}+\gamma X_{i}+\epsilon_{i}
$$

where newly underserved and always underserved are dummy variables indicating practice in corresponding health areas.

We assume that GPs identified as practicing in newly underserved areas are not self-selected, since the declining medical density in their community is only recent (identifying assumption).

All analyses were conducted with SAS 9.4 statistical software (SAS Institute, Cary, NC).

\footnotetext{
${ }^{5}$ In France, private practice GPs are paid based on the fee-for-service system (25 euros per consultation). This regulated-fee results from a negotiation between the government, Social Security and physician representatives. A physician faces a choice: either she accepts regulated-fee remuneration (irrevocable option) or she can charge "with tact and moderation" an excess fee (unregulated fee, can switch to regulated fee afterwards). However, there has been no possibility for new GPs to opt for unregulated fees since 1990.

6 These threshold values correspond to $16 \%$ and $42 \%$ of GPs in our sample.
} 


\section{Results}

Of the $1,553 \mathrm{GPs}$ that consented to the survey being enriched with administrative data ${ }^{7}$, those practicing in relatively underserved areas had greater workload and consultation pace, with no significant difference in declared working hours (Table 1). Their Social Security records reported higher per patient prescriptions of antibiotics and opioids and lower prescription of lab tests and paramedics' consultations, while there was no significant difference in prescription of anti-inflammatory drugs and antidepressants.

\section{-Table 1 here-}

These GPs were also more likely to practice in a rural municipality or one with low median revenue, and less likely to have unregulated fees (Table 2). Their patient list included more younger patients, less elders and less deprived patients.

\section{-Table 2 here-}

Regression results suggest that GPs in relatively underserved areas had longer patient lists and undertook more consultations annually. However, they did not report longer working hours, so it can be concluded that their consultations were shorter (Table 3).

\section{-Table 3 here-}

These GPs also issued more per-patient prescriptions for antibiotics and painkillers (both opioids and other anti-inflammatory products) (Table 4). In contrast, they prescribed less care by nurses and physical therapists. When controlling for density of corresponding paramedics, this result remains significant for nurses, but not for physical therapists. Antidepressant and lab test prescription volumes were not significantly affected by medical density. These results hold in Model 2, when we attempted to control for possible endogeneity of practice location choice (Tables 3-4).

\section{-Table 4 here-}

\footnotetext{
${ }^{7}$ No differences found between respondents giving and refusing consent.
} 
On average, patient lists in underserved areas had 343 patients more than in other areas

(Table 1). Taking into account GPs' characteristics, we estimated the surplus at 306 patients per year (Table 3). One important result regarding the prescriptions was a wider use of opioids in underserved areas: we estimated the gap at 0.13 pills box prescribed per patient in 2013 , other things being equal (Table 4). Finally, there was no significant impact of GP density on total drug prescription and that of lab tests, antidepressants and hypnotics.

Sensitivity analysis (Table 5) suggests that all the indicators related to working conditions and to prescribing opioids and nursing care are robust.

-Table 5 here-

\section{Discussion}

This paper examined how practicing in medically underserved areas impacts the services offered by French GPs. An abundant literature explores the practice differences between urban and rural GPs [13-15]. However, common definitions of rurality remain restrictive, being based solely on total population density without considering physicians' distribution, which can alleviate shortages in rural areas and/or create shortages in urban areas. Our variable of interest (practicing in relatively underserved areas) not only yields insights on both sides of the healthcare market, but also provides relevant zoning of access-to-care flows. Our dataset combines self-reported and administrative data, enabling us to test for differences in declared working conditions (partially perceived) as well as objective prescription practices.

Consistent with the literature, we find that GPs in underserved areas have longer patient lists [14], do more consultations [15] and offer shorter consultations [13]. Conversely (see, for example [14]), we find that GPs in relatively underserved areas do not react to greater demand by increasing their working hours. As far as working-time is concerned, consultation pace seems to act as the sole adjustment variable. 
The finding of more prescriptions for antibiotics and painkillers and fewer for nursing care suggests a "substitution principle", with drugs replacing healthcare professionals. Pain management in particular seems to be affected by poor supply-side conditions. GPs in underserved areas tend to more readily select a prescription for analgesics or antibiotics as the best therapeutic strategy to alleviate pain and/or the risk of infections associated with certain diseases. The general mechanism could be that, under normal supply-side conditions, the availability of the paramedics in the 'monitoring' of the population (particularly the elders) helps to save some prescriptions that are made only for caution (like antibiotics) or for the purpose of pain control (NSAID, opioids); however we know that paramedics are rare in underserved areas ${ }^{8}$, and it is not easy for the population to find a physical therapist or a nurse for the follow-up of care ${ }^{9}$. For physical therapists, this hypothesized substitution-effect is easy to understand [22]. As far as nurses are concerned, we did not find any confirmatory evidence in the literature about this substitution effect, except the mention that nurses are following the pharmaceutical treatment of elders, thus obtaining a better use of drugs [23].

Surprisingly, we find no effect of GP density on total drug prescriptions. One explanation is that this outcome variable is measured as an average monetary value; these averages could be skewed by the most expensive prescriptions - whose spatial distribution is uncorrelated with medical density (e.g. high-price innovative molecules are tested only in very particular places). The absence of significant difference for the use prescription of antidepressants and hypnotics could be related to a tighter management of this type of drug prescriptions, with more precise recommendations [24], although antibiotics or painkillers would remain more elective for the prescribers, therefore, more submitted to contextual considerations.

\footnotetext{
${ }^{8}$ We find a Pearson correlation coefficient between GP density and physical therapists equal to 0.45 in 2013 , at health areas level. The correlation coefficient with self-employed nurses density is equal to 0.26 , but it doesn't take into account nurses employed in health centers. Both coefficients are significant at the $5 \%$ level.

9 As mentioned in the Results section, the introduction of 'paramedics density' in the econometric model of paramedics prescription tends to suppress the significance of the GP density indicator. This seems to suggest that, as far as paramedics underutilization is concerned, low GP density is not an issue per se, but only through its strong correlation with paramedics' spatial distribution. Two effects might take place: either the GP internalizes the shortage of paramedics and prescribes less paramedics visits, or the GP prescribes just as many paramedics visits, but the patients never carry out the visit, so there are no records in the Social Security dataset.
} 
This study has certain limitations. The survey data is cross-sectional and retrospective, making any causal inferences debatable. However, we believe that the strategy of considering only areas where GP density declined between 2007 and 2013 is an identifying method. Another limitation is the way we observe patients' characteristics, which probably explains some of the inter-individual GP variations detected. For data protection reasons, controls were not introduced at individual patient level, but aggregated control variables at GP patient list level being used instead.

Despite all these reservations, our findings suggest that declining medical density significantly impacts the mix of healthcare services offered to patients. In the light of the current effort to better manage "opioid epidemics" [25], our result especially suggests that the forthcoming increase in the number of underserved areas will probably hinder opioid curtailment. Policymakers need to bear this in mind, especially when they have to decide on the magnitude of planning policies aiming at a better geographic distribution of physicians. 


\section{References}

1. OECD Health Statistics 2016 - OECD. http://www.oecd.org/els/health-systems/healthdata.htm. Accessed 11 Feb 2020

2. Bodenheimer, T., \& Pham, H. H. (2010). Primary Care: Current Problems And Proposed Solutions. Health Affairs, 29(5), 799-805.

3. Goddard, M., Gravelle, H., Hole, A., \& Marini, G. (2010). Where Did All the Gps Go? Increasing Supply and Geographical Equity in England and Scotland. Journal of Health Services Research \& Policy, 15(1), 28-35.

4. Correia, I., \& Veiga, P. (2010). Geographic distribution of physicians in Portugal. The European Journal of Health Economics, 11(4), 383-393.

5. Ramos, P., Alves, H., Guimarães, P., \& Ferreira, M. A. (2017). Junior doctors' medical specialty and practice location choice: Simulating policies to overcome regional inequalities. The European Journal of Health Economics, 18(8), 1013-1030.

6. Hartmann, L., Ulmann, P., \& Rochaix, L. (2006). Access to regular health care in Europe. Revue Française Des Affaires Sociales, 2, 121-139.

7. Chevillard, G., Lucas-Gabrielli, V., \& Mousquès, J. (2018). "Medical deserts" in France: Current state of research and future directions. L'Espace géographique, 47(4), 362-380.

8. Grangier J. (2018) Le vieillissement de la population entraîne une hausse des dépenses de santé liées aux affections de longue durée [The aging of the population leads to increasing health care spending related to chronic diseases], Études et Résultats, $n^{\circ} 1077$.

9. Bachelet M, Anguis M (2017) Les médecins d'ici à 2040 : une population plus jeune, plus féminisée et plus souvent salariée [GPs in 2040: younger, female and salaried GPs]. Etudes et Résultats. 1011.

10. Buddeberg-Fischer B, Stamm M, Buddeberg C, Klaghofer R (2008) The new generation of family physicians-career motivation, life goals and work-life balance. Swiss Med Wkly 138:305-312

11. Masseria, C., Irwin, R., Thomson, S., Gemmill, M., \& Mossialos, E. (2009). Primary care in Europe. Policy brief. European Commission.

12. Ferrer RL, Hambidge SJ, Maly RC (2005) The essential role of generalists in health care systems. Ann Intern Med 142:691-699

13. Deveugele M, Derese A, Brink-Muinen A van den, Bensing J, Maeseneer JD (2002) Consultation length in general practice: cross sectional study in six European countries. BMJ $325: 472$

14. Hassel D van, Verheij R, Batenburg R (2019) Assessing the variation in workload among general practitioners in urban and rural areas: An analysis based on SMS time sampling data. Int J Health Plann Manage 34:e474-e486

15. Steinhaeuser J, Joos S, Szecsenyi J, Miksch A (2011) A comparison of the workload of rural and urban primary care physicians in Germany: analysis of a questionnaire survey. BMC Fam Pract 12:112

16. Kann, I. C., Biørn, E., \& Lurås, H. (2010). Competition in general practice: Prescriptions to the elderly in a list patient system. Journal of Health Economics, 29(5), 751-764. 
17. Scott, A., \& Shiell, A. (1997). Analysing the effect of competition on General Practitioners' behaviour using a multilevel modelling framework. Health Economics, 6(6), 577588.

18. Silhol, J., Ventelou, B., Zaytseva, A., \& Marbot, C. (2019). Physicians' Behaviours and Practices: does it make a Difference to Practice in Underserved Areas? Revue française des affaires sociales, 1(2), 213.

19. Le Marechal M, Fressard L, Agrinier N, Verger P, Pulcini C (2017) General practitioners' perceptions of vaccination controversies: a French nationwide cross-sectional study. Clin Microbiol Infect.

20. French Republic, Arrêté du 13 novembre 2017 relatif à la méthodologie applicable à la profession de médecin pour la détermination des zones prévues au $1^{\circ}$ de l'article L. 1434-4 du code de la santé publique [Decree relative to methodology used to define health areas as intended by article L. 1434-4 of the code of public health].

21. Jakoubovitch S, Bournot M-C, Cercier É, Tuffreau F (2012) Les emplois du temps des médecins généralistes [GPs agenda]. Etudes et Résultats. 797.

22. Minor MA., \& Sanford MK. (1999). The role of physical therapy and physical modalities in pain management. Rheumatic Disease Clinics of North America, 25(1), 233-248.

23. Miller CA. (2009). Nursing for wellness in older adults. Lippincott Williams \& Wilkins.

24. Michel-Lepage, A., \& Ventelou, B. (2016). The true impact of the French pay-forperformance program on physicians' benzodiazepines prescription behavior. The European Journal of Health Economics, 17(6):723-32

25. Ruhm CJ (2019) Drivers of the fatal drug epidemic. J Health Econ 64:25-42 


\section{TABLES}

Table 1. Dependent variables, mainland France GPs, 2013-2014, by GP density $(n=1,553)$

\begin{tabular}{|c|c|c|c|c|c|}
\hline & $\begin{array}{l}\text { Underserved } \\
\text { areas }\end{array}$ & $\begin{array}{l}\text { Other } \\
\text { areas }\end{array}$ & $\begin{array}{l}\text { p-value } \\
\text { (Student) }\end{array}$ & Unit & Source \\
\hline \multicolumn{6}{|l|}{ Working conditions } \\
\hline Working hours & 53.7 & 52.5 & 0.38 & Hours per week & Survey \\
\hline Patient list & 1,821 & 1,478 & $<0.01$ & $\begin{array}{l}\text { Number of different } \\
\text { patients seen in } \\
2013\end{array}$ & \multirow{2}{*}{$\begin{array}{c}\text { Administrative data } \\
\text { (Social Security - } \\
\text { CNAM) }\end{array}$} \\
\hline Workload & 5,701 & 4,691 & $<0.01$ & $\begin{array}{c}\text { Consultations and } \\
\text { house calls in } 2013\end{array}$ & \\
\hline Consultation pace & 2.65 & 2.2 & $<0.01$ & $\begin{array}{c}\text { Number of patients } \\
\text { per hour worked } \\
\text { (including } \\
\text { administrative tasks) }\end{array}$ & $\begin{array}{l}\text { Estimation based on } \\
\text { reported and } \\
\text { administrative data } \\
\text { (Social Security - } \\
\text { CNAM) }\end{array}$ \\
\hline \multicolumn{6}{|l|}{ Prescription practices } \\
\hline Antibiotics (J01) & 0.93 & 0.84 & 0.02 & \multirow{4}{*}{$\begin{array}{l}\text { Number of pill boxes } \\
\text { prescribed per } \\
\text { patient in } 2013\end{array}$} & \multirow{7}{*}{$\begin{array}{c}\text { Administrative data } \\
\text { (Social Security - } \\
\text { CNAM) }\end{array}$} \\
\hline Opioids (N02A) & 0.79 & 0.67 & $<0.01$ & & \\
\hline $\begin{array}{l}\text { Anti-inflammatory and } \\
\text { antirheumatic products, } \\
\text { non-steroids (M01A) }\end{array}$ & 0.71 & 0.67 & 0.11 & & \\
\hline $\begin{array}{l}\text { Antidepressants } \\
(\text { N06A) }\end{array}$ & 0.49 & 0.49 & 0.99 & & \\
\hline Lab tests & 101.4 & 111.7 & $<0.01$ & \multirow{3}{*}{$\begin{array}{l}\text { Coefficients }^{b} \\
\text { prescribed per } \\
\text { patient in } 2013\end{array}$} & \\
\hline Nurses & 9.8 & 16.2 & $<0.01$ & & \\
\hline Physical therapists & 13.2 & 18.3 & $<0.01$ & & \\
\hline
\end{tabular}

Notes: weighted data

Anatomical Therapeutic Chemical Classification (ATC) used for drug prescription.

a Including phenothiazines with aliphatic side-chain (N05AA).

${ }^{b}$ In the French Social Security Medical classification for Clinical Procedures, each procedure is defined by a given coefficient which indicates the relative value of the act (the coefficient attributed to a procedure is determined by its complexity, i.e. venipuncture corresponds to 1.5 coefficients for an adult patient and to 5 coefficients for children under 5 years old). Each coefficient has a monetary value: for services in mainland France in 2013 the value of 1 coefficient was 2.15 euros for physical therapists, between 2.5 and 3 euros for nurses and between 0.27 and 2.52 euros for lab tests. For illustration, depending on GPs, the average value of per-patient lab tests prescriptions was between 27.4 euros and 255.5 euros, for GPs practicing in underserved areas. 
Table 2. Control variables, mainland France GPs, 2013-2014, by GP density $(n=1,553)$

\begin{tabular}{|c|c|c|c|}
\hline & Total & Not underserved & Underserved \\
\hline Observations $^{a}$ & 1,553 & 1,131 & 422 \\
\hline \multicolumn{4}{|c|}{ GPs personal and professional characteristics } \\
\hline Women & $30.6 \%$ & $31.3 \%$ & $28.4 \%$ \\
\hline \multicolumn{4}{|l|}{ Age } \\
\hline$<50$ years old $(\mathrm{Q} 1)$ & $30.6 \%$ & $31.2 \%$ & $28.8 \%$ \\
\hline > 58 years old $(\mathrm{Q} 4)$ & $36.8 \%$ & $36.4 \%$ & $38.0 \%$ \\
\hline Unregulated fees & $9.3 \%$ & $10.5 \% * * *$ & $5.4 \% * * *$ \\
\hline Group practice & $54.7 \%$ & $54.9 \%$ & $54.1 \%$ \\
\hline \multicolumn{4}{|l|}{ Practice municipality characteristics } \\
\hline Rural municipality & $16.3 \%$ & $14.6 \% * * *$ & $21.6 \% * * *$ \\
\hline Practice located in Paris & $3.4 \%$ & $3.8 \%$ & $2.3 \%$ \\
\hline \multicolumn{4}{|l|}{ Municipality median revenue ${ }^{b}$} \\
\hline Q1 & $23.6 \%$ & $22.3 \%$ ** & $27.5 \% * *$ \\
\hline Q4 & $26.6 \%$ & $25.2 \%$ & $23.1 \%$ \\
\hline \multicolumn{4}{|l|}{ Patients' characteristics } \\
\hline $\begin{array}{l}\text { Proportion of patients aged }<16 \text { years, } \\
\text { average }\end{array}$ & $20.9 \%$ & $20.3 \%{ }^{* * *}$ & $22.8 \% * * *$ \\
\hline $\begin{array}{l}\text { Proportion of patients aged } \geq 60 \text { years, } \\
\text { average }\end{array}$ & $24.7 \%$ & $25.1 \% * *$ & $23.6 \% * *$ \\
\hline Proportion of deprived patients, average & $7.8 \%$ & $8.0 \%$ * & $7.2 \%{ }^{*}$ \\
\hline
\end{tabular}

Notes: weighted data

Chi-square and ANOVA test results: ${ }^{*} p<0.1,{ }^{* *} p<0.05,{ }^{* * *} p<0.01$.

a Unweighted

b Source: Insee open data (https://insee.fr/fr/statistiques/2388413) 
Table 3. Factors associated with GPs working conditions

\begin{tabular}{|c|c|c|c|c|c|c|}
\hline & \multicolumn{2}{|c|}{ Patient list } & \multicolumn{2}{|c|}{ Workload } & \multicolumn{2}{|c|}{ Consultation pace } \\
\hline & Model 1 & Model 2 & Model 1 & Model 2 & Model 1 & Model 2 \\
\hline $\begin{array}{l}\text { Density in } 2013 \text { (ref. Not } \\
\text { underserved) }\end{array}$ & $\begin{array}{c}305.53^{\star * *} \\
(35.36)\end{array}$ & - & $\begin{array}{l}937.23^{* * *} \\
(126.26)\end{array}$ & - & $\begin{array}{l}\mathbf{0 . 4 2 * * *} \\
(0.10)\end{array}$ & - \\
\hline \multicolumn{7}{|c|}{ Density in 2013 compared to 2007} \\
\hline Newly underserved & - & $\begin{array}{c}299.20^{* * *} \\
(48.09)\end{array}$ & - & $\begin{array}{l}915.33^{* * *} \\
(172.62)\end{array}$ & - & $\begin{array}{l}\mathbf{0 . 5 1} \mathbf{1}^{* * *} \\
(0.14)\end{array}$ \\
\hline Always underserved & - & $\begin{array}{c}323.86^{* * *} \\
(44.33)\end{array}$ & - & $\begin{array}{l}\mathbf{9 7 0 . 8 4} 4^{\star * *} \\
(159.11)\end{array}$ & - & $\begin{array}{l}\mathbf{0 . 3 6} \\
(0.13)\end{array}$ \\
\hline Observations & 1,503 & 1,482 & 1,503 & 1,482 & 1,503 & 1,482 \\
\hline $\mathrm{R}^{2}$ & 0.25 & 0.25 & 0.23 & 0.23 & 0.07 & 0.07 \\
\hline
\end{tabular}

Note. Non-weighted data.

Standard errors in brackets.

Controls are described in text.

Other dependent variables were analyzed, with no significant correlation with GPs' density: working hours (per week).

${ }^{*} p<0.1,{ }^{* *} p<0.05,{ }^{* * *} p<0.01$. 
Table 4. Factors associated with GPs prescription practices

\begin{tabular}{|c|c|c|c|c|c|c|c|c|c|c|c|c|c|c|}
\hline & \multicolumn{2}{|c|}{ Antibiotics (J01) } & \multicolumn{2}{|c|}{ Opioids (N02A) } & \multicolumn{2}{|c|}{$\begin{array}{c}\text { Anti-inflammatory and } \\
\text { antirheumatic products, } \\
\text { non-steroids (M01A) }\end{array}$} & \multicolumn{4}{|c|}{ Nurses } & \multicolumn{4}{|c|}{ Physical therapists } \\
\hline & Model 1 & Model 2 & Model 1 & Model 2 & Model 1 & Model 2 & Model 1 & Model 1a & Model 2 & Model 2a & Model 1 & Model 1a & Model 2 & Model 2a \\
\hline $\begin{array}{l}\text { Density in } 2013 \\
\text { (ref. Not } \\
\text { underserved) }\end{array}$ & $\begin{array}{l}\mathbf{0 . 0 7}{ }^{* *} \\
(0.03)\end{array}$ & - & $\begin{array}{l}\mathbf{0 . 1 3}{ }^{* * *} \\
(0.03)\end{array}$ & - & $\begin{array}{l}\mathbf{0 . 0 5} 5^{\star *} \\
(0.02)\end{array}$ & - & $\begin{array}{c}-4.55^{\star * *} \\
(0.91)\end{array}$ & $\begin{array}{l}-1.54^{*} \\
(0.83)\end{array}$ & - & - & $\begin{array}{c}-3.54^{\star * *} \\
(0.73)\end{array}$ & $\begin{array}{l}-0.57 \\
(0.71)\end{array}$ & - & - \\
\hline \multicolumn{15}{|c|}{ Density in 2013 compared to 2007} \\
\hline $\begin{array}{l}\text { Newly } \\
\text { underserved }\end{array}$ & - & $\begin{array}{l}\text { 0.09** } \\
(0.04)\end{array}$ & - & $\begin{array}{l}\mathbf{0 . 0 8} \\
(0.04)\end{array}$ & - & $\begin{array}{c}0.04 \\
(0.03)\end{array}$ & - & - & $\begin{array}{c}-4.07^{* * *} \\
(1.24)\end{array}$ & $\begin{array}{l}-1.24 \\
(1.13)\end{array}$ & - & - & $\begin{array}{c}-3.37^{\star * *} \\
(0.99)\end{array}$ & $\begin{array}{l}-0.85 \\
(0.95)\end{array}$ \\
\hline $\begin{array}{l}\text { Always } \\
\text { underserved }\end{array}$ & - & $\begin{array}{c}0.07 \\
(0.04) \\
\end{array}$ & - & $\begin{array}{c}\mathbf{0 . 1 6} \\
(0.03) \\
\end{array}$ & - & $\begin{array}{l}\mathbf{0 . 0 5 ^ { * }} \\
(0.03)\end{array}$ & - & - & $\begin{array}{c}-5.30^{* * *} \\
(1.15) \\
\end{array}$ & $\begin{array}{l}-\mathbf{2 . 0 0 *} \\
(1.05)\end{array}$ & - & - & $\begin{array}{c}-3.89 * * * \\
(0.92) \\
\end{array}$ & $\begin{array}{l}-0.49 \\
(0.90)\end{array}$ \\
\hline Density of nurses & No & No & No & No & No & No & No & Yes & No & Yes & No & No & No & No \\
\hline $\begin{array}{l}\text { Density of } \\
\text { physical therapists }\end{array}$ & No & No & No & No & No & No & No & No & No & No & No & Yes & No & Yes \\
\hline Observations & 1,503 & 1,482 & 1,503 & 1,482 & 1,503 & 1,482 & 1,503 & 1,503 & 1,482 & 1,482 & 1,503 & 1,503 & 1,482 & 1,482 \\
\hline $\mathrm{R}^{2}$ & 0.10 & 0.10 & 0.20 & 0.20 & 0.15 & 0.15 & 0.26 & 0.40 & 0.40 & 0.40 & 0.17 & 0.27 & 0.27 & 0.27 \\
\hline
\end{tabular}

Note. Non-weighted data.

Standard errors in brackets.

Controls are described in text.

Anatomical Therapeutic Chemical Classification (ATC) used for drug prescription.

Other dependent variables analyzed, with no significant correlation with GPs' density: total drug prescription (per patient); lab tests; antidepressants (N06A)

including phenothiazines with aliphatic side-chain (N05AA); hypnotics and sedatives (N05C) excluding butobarbital (N05CA03) and barbiturates in combination

with other drugs (N05CB02); including meprobamate, combinations (N05BC51).

${ }^{*} \mathrm{p}<0.1,{ }^{* *} \mathrm{p}<0.05,{ }^{* * *} \mathrm{p}<0.01$ 
Table 5. Sensitivity results for practice in underserved area

\begin{tabular}{|c|c|c|c|c|c|c|}
\hline \multicolumn{2}{|c|}{ Dependent variables } & \multicolumn{2}{|c|}{$\beta$} & \multirow{2}{*}{$\begin{array}{c}\text { Observations } \\
1,503\end{array}$} & \multirow{2}{*}{$\begin{array}{c}\mathbf{R}^{\mathbf{2}} \\
0.25 \\
0.25 \\
0.25\end{array}$} & \multirow{2}{*}{$\begin{array}{c}\text { Robust/fragile } \\
\text { robust }\end{array}$} \\
\hline \multirow{3}{*}{$\begin{array}{l}\text { Working } \\
\text { conditions }\end{array}$} & Patient list & $\begin{array}{l}\text { high: } \\
\text { base: } \\
\text { low: }\end{array}$ & $\begin{array}{l}259.34^{\star * *} \\
305.53^{\star * *} \\
324.45^{\star * *}\end{array}$ & & & \\
\hline & Workload & $\begin{array}{l}\text { high: } \\
\text { base: } \\
\text { low: }\end{array}$ & $\begin{array}{l}779.38^{\star * \star} \\
937.23^{\star * \star} \\
935.68^{\star * *}\end{array}$ & 1,503 & $\begin{array}{l}0.23 \\
0.23 \\
0.22 \\
\end{array}$ & robust \\
\hline & Consultation pace & $\begin{array}{l}\text { high: } \\
\text { base: } \\
\text { low: }\end{array}$ & $\begin{array}{l}0.37^{\star * *} \\
0.42^{\star * *} \\
0.31^{\star *} \\
\end{array}$ & 1,503 & $\begin{array}{l}0.07 \\
0.07 \\
0.07\end{array}$ & robust \\
\hline \multirow{3}{*}{$\begin{array}{l}\text { Drug } \\
\text { prescriptions (per } \\
\text { patient) }\end{array}$} & Antibiotics (J01) & $\begin{array}{l}\text { high: } \\
\text { base: } \\
\text { low: }\end{array}$ & 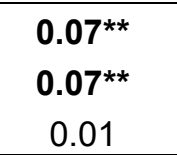 & 1,503 & $\begin{array}{l}0.10 \\
0.10 \\
0.09\end{array}$ & fragile \\
\hline & Opioids (N02A) & $\begin{array}{l}\text { high: } \\
\text { base: } \\
\text { low: }\end{array}$ & $\begin{array}{l}0.14^{\star * *} \\
0.13^{\star * *} \\
0.07^{\star *}\end{array}$ & 1,503 & $\begin{array}{l}0.21 \\
0.20 \\
0.19\end{array}$ & robust \\
\hline & $\begin{array}{c}\text { Anti-inflammatory } \\
\text { and antirheumatic } \\
\text { products, non- } \\
\text { steroids (M01A) }\end{array}$ & $\begin{array}{l}\text { high: } \\
\text { base: } \\
\text { low: }\end{array}$ & $\begin{array}{c}0.03 \\
\mathbf{0 . 0 5 ^ { \star * }} \\
0.02 \\
\end{array}$ & 1,503 & $\begin{array}{l}0.15 \\
0.15 \\
0.15\end{array}$ & fragile \\
\hline \multirow{2}{*}{$\begin{array}{l}\text { Paramedics } \\
\text { prescriptions } \\
\text { (per patient) }\end{array}$} & Nurses & $\begin{array}{l}\text { high: } \\
\text { base: } \\
\text { low: }\end{array}$ & $\begin{array}{l}-4.93^{\star * *} \\
-4.55^{\star * *} \\
-4.51^{\star * *}\end{array}$ & 1,503 & $\begin{array}{l}0.40 \\
0.40 \\
0.40\end{array}$ & robust \\
\hline & $\begin{array}{l}\text { Physical } \\
\text { therapists }\end{array}$ & $\begin{array}{l}\text { high: } \\
\text { base: } \\
\text { low: }\end{array}$ & $\begin{array}{l}-4.00^{* * *} \\
-3.54^{* * *} \\
-3.60^{* * *}\end{array}$ & 1,503 & $\begin{array}{l}0.27 \\
0.27 \\
0.27\end{array}$ & robust \\
\hline
\end{tabular}

Notes: The base $\beta$ is the estimated coefficient from the regression with the variable of interest (relatively underserved in 2013), where an area is considered relatively underserved if GPs density is lower than 8. The high $\beta$ is the estimated coefficient from the regression where an area is considered relatively underserved if GPs density is lower than 9 . The low $\beta$ is the estimated coefficient from the regression where an area is considered relatively underserved if GPs density is lower than 7 .

A fragile coefficient is defined as a coefficient that does not remain significant or changes sign. 